\title{
The Impacts of Foreign Share Holders on Turkish Banking System the Profitability Change of Akbank
}

\author{
Ahmet Salih İkiz \\ Muğla Sitkı Kocman University, Mugla, Turkey
}

\begin{abstract}
The theoretical frame in economics assumes that foreign banks invest abroad in order to increase their profits. This is one of the main drivers of FDI to host companies. Main idea behind that is raising the profitability of invested local banks. Turkey attracted important amount of foreign investment to banking sector after the 2001 economic crisis. In this study after discussing the main incentives of foreign banks for the transfer of capital to Turkey, the author will clearly investigate the impacts of recent bank buyout operations in Turkey. Akbank which is one of the oldest banks in the sector as most of the local banks sold $20 \%$ of its share to a Citigroup. This paper will examine the change of profitability ratio of this bank after this operation in order to check theoretical assumptions.
\end{abstract}

Keywords: Turkish banking sector, Akbank, Foreign banks, money \& banking, FDI, Citibank

\section{Historical Review of Turkish Banking System Regarding to Foreign Banks}

One of the main derives of foreign banking groups to buy banks in other countries is high profitability in sector. Turkish banking sector had managed to maintain sound and credible performance and attracted many foreign banks in last decade. Major Turkish Banks such as Garanti, Akbank, YapiKredi, and Denizbank have foreign banking partners.

After two serious economic crises in 1994 and 2001, Turkish banking sector had achieved to maintain solid growth and strength. Bank portfolios have great achievement. That performance attracted foreign investment in Turkish banking sector. Also IMF's policies for countries like Turkey highly refer low exchange rate and comparatively high interest rate. That also flourishes foreign direct investment in Turkey.

Banks do play an important role in countries financial sectors. They are the main determinants of the robustness of countries economic performance. Their main functions can be shortly listed as follows:

- Bank establishes a market for fund suppliers and credit seekers;

- These institutions provide service for financial transactions;

- These financial intermediaries increase the money supply by creation of bank money.

With those functions in a globalized world, banks create a unique transport line for monetary transaction between countries. Especially in countries in transition the banking sector plays a vital role for new investments in industrial sector which in turn increases the Gross Domestic Product (GDP) of those countries. In following part of the study the clear brief history of Turkish banking sector is explained.

The banking system has its own roots till 19 century in old Ottoman Empire. Since traditional Islamic

Ahmet Salih İkiz, Ph.D., Economics Department, Muğla Sttkı Kocman University.

Correspondence concerning this article should be addressed to Ahmet Salih İkiz, Mugla Sitki Kocman University, Mugla, Turkey. E-mail: ahmet@mu.edu.tr. 
belief forbidden interest payments in lending Turkish people are reluctant to involve in baking sector. The first bank in European standards has founded in Galata in 1847 by minorities of Empire called Banque de Constantinople (Erdem, 2010). Those times the marketing of Ottoman bonds to European countries was one of the main operations of those bankers. Collapsing Ottoman Empire was demanding extra financial resources in order to finance heavy burden of government expenses. Locally owned first bank has own roots till 1867 by Mithat Pasha and today called "Agricultural Bank of Republic of Turkey". Soon after Ottoman Empire had disappeared from history and that brought another step in Turkish financial sector.

The foundation of Turkish Republic was a transformation from traditional society to modern world for Turkish citizens. The implementation of western democratic governance formed new state structure for Turkey. The founding fathers of Turkey set aside that modernization of country related with the acceptance of westernization (Bache, 2011). This tremendous paradigm shift has also got impact on Turkish banking sector. After Domini of Turkish Republic new government followed contemporary economic growth models in order to integrate western world. In the meantime, banking system emerged was similar to the western world. In early years, important numbers of state banks had founded in order to finance investments in mining, textiles, and heavy industries. So the share of public was quite high due to insufficient private sector savings to be channeled to invest in banking sector for a long period of time. Till the beginning of 1980s, banking sector overwhelmingly dominated by public sector. Interest rates are determined by state authorities and it has very few incentives to support reel sector for new investments. Banking institutions were functioning as hoarding agencies in Turkish financial sector. Following deregulation policies after 1980s, there was a challenge in banking sector operations. Especially after 1990 banking sector started to finance both public and private enterprises. One of the main outcomes of financing public sector is the limitation of funds for private enterprises. High yield of Treasury bonds and bills increased the demand for them at the expense of private sector bonds. Crowding out effect of public sector borrowing became inevitable. In the meantime, short term speculative foreign currency transfer increased due to the high return on Turkish lira bond and bills (Ozatay, 2011). That brought Turkey to threshold of famous 2001 financial crisis which has even reflections on political system. The result was collapse of half of the whole banking system. They bankrupt, left from market and get under the supervision of state agency called Banking Regulation and Supervision Agency. The outcome on industrial sector was even worse and country experienced minus growth in that year.

\section{Comparison of Turkish Banking With EU Countries}

Following the crisis country had experienced revolutionary change in socio-economic life where both sustained high level growth in economics with moderate Islamic government. There is a radical change in the structure of civil state authority. It has cultural ties with Balkan and Middle East countries for centuries. That also attracted Foreign Direct Investment (FDI) to country from abroad. In order to get benefit from the region, western banks especially from Europe increased their buying operations in Turkey. The size and volume of European banks are importantly bigger than Turkish banks. Table 1 shows main determinants of EU 27 countries and Turkey by ratio analyses.

In Table 1, the comparison between European banks and Turkish banks reveals that the EU banking system have much sufficient assets compared with Turkish banking sector. The overall comparison between EU 27 and Turkey also give clear evidence that there are more banks per capita in European border than Turkish banks. This information can give us that why foreign banks are so keen to enter Turkish market. It is 
also related with European Union integration process. According to World Bank resources, Turkish banks fulfilled the conditions required for the banking sector to comply with integration process of EU. Within the National Program, necessary legislation has already made (Togan, 2005). As happened to most accession countries, the European Union membership shifted the ownership structure of national banking system as shown in Table 2.

Table 1

Banking Sector Analyses for EU 27 and Turkey (2008)

\begin{tabular}{lrr}
\hline Ratio analyses & EU 27 & Turkey \\
\hline Per capita bank assets (Euro) & 84,711 & 5,453 \\
Total assets/GDP (\%) & 337 & 77 \\
Population/Number of staff & 149 & 389 \\
Population/Number of branches & 2,092 & 7,640 \\
Population/Number of banks & 58,550 & $1,459,531$ \\
\hline
\end{tabular}

Note. Source: Turkish Banking Association Annual Report (2011).

Table 2

Shares of Foreign Banks in New European Union Members (\%)

\begin{tabular}{lcll}
\hline Years & 1994 & 1999 & 2001 \\
\hline Czech Republic & 5.8 & 49.3 & 90 \\
Hungary & 19.8 & 56.6 & 88.8 \\
Poland & 2.1 & 52.8 & 68.7 \\
\hline
\end{tabular}

Note. Source: Banking Regulation and Supervision Agency Turkey (2011).

In this case, it is expected that the share of foreign banks in Turkey will increase in coming years. The privatization of public owned banks would play an important role in this stage. In the following chapter of the article, the author will explain the factors stimulating foreign capital investments in banking sector.

\section{Main Factors for Foreign Banking Investments}

The logic of foreign bank investment is mainly twofold. Foreign banks invest in other countries either due to the company's strategic inner policies or the economic structure of host country. Both factors can be explained as follows.

\section{Investment as Company Policy}

Those factors are mainly related to companies board of managers decision and related to banks own decision making process. They are as follows:

- Banks do invest foreign markets in order to reach profit maximization. Especially low return in home country forces foreign banks to invest and operate abroad;

- Foreign banks do wish to exploit the low risked high income segmented customers in foreign countries by opening new branches;

- Foreign banks wish to maintain risk minimization via operating different countries with contradictory risk structure and stay risk averse.

\section{External Factors Related With Host Country}

These factors are highly related with the socioeconomic structure of invested country, which are:

- High profit margin and credit interest rates in host country;

- Effective and productive privatization policy in countries in transition; 
- Potential high economic growth in host country;

- Low price of banking sector shares in stock exchange in host country;

- Potential high benefits of bank ownership in host country;

- Incentives for foreign direct investment in banking sector.

After the last globalization wave in world, the vast amount of money being transferred all around to globe via electronic fund transfer methods. Fund owners aim to get much more profit from host countries. So that capital rather prefers stable ports in world countries. There is a high tendency in economic literature that foreign banks have stabilized host country's financial system and improve efficiency in banking sector. During the Europeanization, most of the new members of EU as Bulgaria and Romania achieved to stabilize their financial system by attracting foreign direct investments. Foreign banks have maintained sound and productive fiscal system and multiplied economic progress in countries in transition in Eastern Europe.

There are also some negative impacts of foreign banks as deepening the economic crisis by transferring funds to abroad in order to avoid financial losses during crisis. The movement of that hot money incredibly affects the impacts of the economic crisis in host country. Past Mexican and Argentinean financial crisis was seriously hampered by flow of foreign banking groups in early stages of fiscal problem. Thus, foreign banks did deepen the crisis by leaving host countries in the early stages of economic disasters. Destabilization effects of foreign banks rendered the theoretical framework of financial economics.

During the past economic crisis period after 2001, Turkey experienced vast amount of capital transfer from foreign banking groups. The profitability of banking sector and richness of its hinterland for banking operations attracted profit seeking foreign banking groups to Turkey. Most of the Turkish private banks sold foreign groups. Some foreign banks did have controlling interest of some Turkish banks by buying shares of them. One of the very prominent examples was Citibank Akbank marriage in 2007. In following parts of the study this case is discussed in detail.

\section{Foreign Banks in Turkey: The Case of Akbank}

In macro-economic theory, the impacts of foreign banking investments on host country discussed from different views. The optimist approach had argument that those investments like others have positively affect country by increasing GDP growth, providing access to global markets and creation benefits of welfare effects by increasing employment. So in the long term, the stabilization effects of foreign banks would be higher for host country. The high ratio of foreign capital in economy increases the integration world economy and improves the welfare of country.

In contrary pessimist economists argue that foreign banks do prefer countries with high yields on their investments. In the case of political unrest or economic crisis, they have higher tendency to leave the country. That multiplies the hazard of economic crisis since it loses important amount of foreign monetary resources. That abandons the capital accumulation of those countries by diminishing currency insufficiency. High volatility of short term capital movements will have adverse effects on developing countries. Very recent example was the collapse of important German banks due to the contamination effects of US banking crisis (Roubini, 2012).

After the improvements in Turkish economy, the foreign banks did start to invest Turkish market. They either open their subsidiaries or bought the shares of Turkish banks in Istanbul Stock Exchange. The share of foreign banks is around $17 \%$ in all banking assets. Concerning the Turkish banks with foreign partners with 
that reveals half of the Turkish banking sector owned by foreign capital groups. Their risk taking behavior of entering Turkish market positively affected Turkish economy. In this case, it would better to discuss cost benefit analyses of foreign banks.

Main benefits of foreign banks to Turkish banking system are as follows. Those banks are located in the main financial centers in world and important amount of capital stocks, which would increase our ability to reach international markets and operations. European Union membership process will be positively affected by the penetration of main European banks as integration process will be strong and healthy. Turkish banks may easily open new branches and locate in new markets via foreign partners. Turkish banking sector will more productive and effective by new products and techniques provided by foreign partners. The profitability, dividend yield, and share prices of Turkish banks with foreign partners in Istanbul Stock Exchange will increase.

Besides, those benefits are possible costs of foreign banks in sector. Foreign banks usually transfer their profits to abroad headquarters. As both in 1994 and 2001 economic crisis in Turkey, foreign banks may leave in possible economic crisis. The marketing policy is much more risk averse and their costs are lower compared with local banks. That may lower the profit margins of local banks.

According to TBA figures, the return on assets for private banks is $1.7 \%$ and return on equity is $14.4 \%$ in 2011 in Turkey. This figure is lower compared with 2008 which is $2.5 \%$ and $17 \%$ respectively. Thus, the foreign bank partnership has lessened the profitability of Turkish banking sector. This is mainly related the operation policies of foreign capital groups. They did have priority of following Basel II criteria's. The high share of shadow economy in Turkish GDP respectively forced small and medium enterprises do some balance sheet accounting operations. Then enterprises provide different accounting profit than official one. That sort of operation restricts the firm's ability to get credit line from banks.

The 2007 world financial crisis started with future and options operations of main international banks. Most of the Turkish banks do not involve in this sort of derivative operations. But it is well known that Turkish banks with foreign partners are providing credits to Turkish customers from abroad since the return on Turkish lira is still very high. Any increase in exchange rate would increase the riskiness of those operations and may create another wave of financial collapse in Turkey. This globalized financial world would create domino effect in regional context. Alternative path of the foreign banks in Turkey related with Turkish growth strategy. If my country achieves strong economic standards and be a regional player it can easily attract more funds from Middle East and Gulf countries. The combination of European Union membership creates universal bridge between east and west. The popularity of Turkey is rising abroad. Turkey judged by most of the refugees that the best country to live from Singapore to Athens where refuges wish to live because of its prosperity (Stone, 2010). Arab spring and other new developments in this region would positively impact Turkish portfolio in the region. In the meantime, low rate of return in European markets will also flourish Turkish banking sector. Thus it is expected that positive decomposition of Turkish banking sector from world banking will provide benefits to Turkish economy. Even one of the leading economists Jim O'Neil classified Turkey as one of the Mexican, Indonesia, South Korea, and Turkey (MIST) countries which will be dominant in world economy in the coming decade. According to this author's opinion, even Brazil, Russia, India, and China (BRIC) will be replaced by MIST in near future.

The share of foreign banks in total assets of sector was quite low till 2001 economic crisis. The evaluation period after harsh economic crisis improved the strength of Turkish banking sector. After the crisis, most of the 
private banks either bankrupt or passed under state supervision. State authority sold some banks after the cleanup process of their assets and liabilities. Some medium sized banks such as Garantibank, YapıKredi, and others preferred to have foreign partners from well known western banks.

After the evaluation macro level developments of foreign capital in Turkish banking sector, the author will focus on micro level to search one unique bank. Akbank founded in 1948 in Adana in order to support cotton producers and mill owners. After moving its head office to Istanbul in 1954, it managed a tremendous growth and became well known in all around Turkey. After floated to public in 1990, banks shares have been traded in Istanbul Stock Exchange. Today, it is one of the main banks in Turkish banking sector. In 2007, globally well-known Citibank bought $20 \%$ of Akbank for operation purpose in regional context. After the marriage the Citigroup had dominant controlled most of the decisions of daily operations of bank. During the Citigroup management bank was seriously strictly followed BASEL criteria's in evaluation process of credit applications to bank. That decreased credits to SME's since they are mainly working in shadow sector with unrecorded income and expenditures. That was also hampered banking revenues due to low credit marketing figures. This marriage has ended in 2012 with a Citigroup decision to end partnership by selling company shares to former owners. In this part of the article, the author will search how Akbank's profitability changed after Citibank operation.

During the partnership, Akbank increased the number of branches from 715 to 926 and number of staff increase from 13,513 to 15,339. In the same period, Akbank lost its momentum in profitability which means that globally well-known Citibank as a partner rather negatively affect Akbank's profitability. Although bank managed to sustain its place in big five in Turkish banking system the gradual diminish in profits became inevitable. The comparison of profitability before and after Citigroup operation clearly shows the negative performance of Akbank.

In this study, TBA dataset which provides very reliable ratio analyses has used. Ratio analyses are one of the main methods in financial management. That allows analysts and strategists to compare the company's performance during the time process (Akguc, 1989). The overall comparison of post Citibank operation with pre-Citibank ownership would give clear evidence about the changing nature of Akbank's assets and profitability.

Table 3

Akbank Profitability After Citibank Partnership

\begin{tabular}{lrr}
\hline Capital \& Profitability ratios & 2006 & 2011 \\
\hline Shareholders equity/total assets & 12.3 & 13.1 \\
Total loans and receivables/total deposits & 82.9 & 91.5 \\
Liquid assets/total assets & 47.3 & 41.6 \\
Net profit/total assets & 2.8 & 1.8 \\
Net profit/total shareholders' equity & 22.7 & 13.6 \\
\hline
\end{tabular}

Note. Source: Turkish Banking Association Annual Report (2011).

In the light of theoretical review in previous part of the author's study, it is expected that foreign banks supposed to be improve the profitability of host banks. The efficiency and profitability of local banks are expected to improve with contemporary and global management skills of international banking companies. These are the positive externalities of foreign capital inflow on local partners. That hypothesis falsified by the data in this article since Akbank became less profitable after Citigrup operation. The results of that joint 
partnership of those banks revealed totally different outcome since local bank lost its momentum in profitability in sector. This is mainly related to global financial crisis started in US with Lehman Brothers collapse. The loss of profit of Citibank in US operations also made negative impacts in its subsidiaries in overseas like Turkey. Thus it revealed that global economic crisis make national banks with foreign partners more vulnerable to the external shocks. The decision of Citibank for buying shares of Turkish bank is rather related to strong macro-economic performance of Turkish economy than related with Akbank. High growth rate, low inflation, and easy penetration to markets in Middle East and Balkans made Turkish banks more attractive to foreign banking companies. Turkey has fewer regulations for foreign banks compared with European banking authorities, so most of the Western banks had partnerships with Turkish banks in last decade.

\section{Conclusions}

This article has explored the impact of foreign banks on Turkish banking sector. We identified the emergence of foreign banks and their levels of penetration in Turkey. There is a theoretical discovery of the incentives of foreign banks to invest other countries. The pros and cons for foreign banks in host country were shortly discussed. In the final part of the study, the growing importance of Turkey has discussed in world economy. As we all know Turkey in crossroads and final experience will positively affect Turkey.

Our research had investigated the change in the profitability of Akbank after Citibank partnership. It is quite clear that Akbank had less profit on its assets on equities after 2007, although it may help Turkish party to improve the international integration to western banking sector that positive impact had overthrown by decline in profitability. Also stability effects of foreign banks would easily turn vice versa by high potential of leaving host countries during the crisis period.

Liberalization history of Turkey was full of economic crisis. The low exchange rate parity and high interest rate compared with world markets attracted foreign capital inflow to Turkey before every crisis. In all cases, short term capital left host country after the first indicators of financial crisis. The author does not wish to make generalization of this argument for all cases but that would show us the fragility of world financial system. The vulnerability of each countries risk of financial collapse makes them to contaminate the risk of spreading the financial problem to other countries. In our case, the problems of Citigroup easily contaminated to Turkish companies and forced foreign banking group to leave the market.

Although Turkish banking sector is much better in strength compared with 2001 period, any short term capital out flow may create problems in near future. Sustainability of exchange rate policy would be somehow quite fragile if we have further current account deficit which is highly related increase in oil prices.

\section{References}

Akguc, O. (1989). Financial management. Istanbul: Istanbul University Accounting Institutes publications.

Bache, I. (2011). Politics in the European Union. UK: Oxford University Press.

Banking Regulation and Supervision Agency Annual Report. (2011). Ankara, Turkey.

Erdem, E. (2010). Money banking and finacial system. Turkey: Detay Publication.

Ozatay, F. (2011). Monetary economics, theory and policy. Turkey: Efil Publications.

Roubini, N. (2012). Crisis economics. Turkey: Pegasus Publications.

Stone, N. (2010). Turkey: A short story. London: Thames \& Hudson.

Togan, S. (2005). Turkey economic reform \& accession to the European Union. Worldbank and the Cenre for Economic Policy Research publications.

Turkish Banking Association Annual Report. (2011). Ankara, Turkey. 